consortium of three independent laser facilities to deliver images at the atomic level.

The project is part of a roadmap for European research infrastructure - a wish list of research facilities drawn up by the best scientific minds across the European Union (EU) - and the first to be built in newer, and often less-well-off, member states.

The ELI is on track to begin construction early next year, but the real test starts now. To build it, the host countries will use EU structural funds - a multi-billion-euro pot established to help narrow the economic and social disparities between member states. Earlier this year, Máire Geoghegan-Quinn, European Commissioner for Research, Innovation and Science, said she hoped to divert $€ 86$ billion of EU structural funds to building Europe's "knowledge economy", including research infrastructure. In the past, it has been difficult to track how countries have spent such structural funds, and this lack of transparency has led to a sense of mistrust. As a result, policy wonks in established member states are questioning the merits of using structural funds to support research in Europe, such as on the ELI.

Poland is a major beneficiary of structural funding for research infrastructure, and has been allocated $€ 1$ billion over the period 2007-2013. Critics of the approach were handed ammunition earlier this year, when Poland invited a panel of international scientists to assess the research infrastructure it wants to build in the future, partly using structural funds. The country should be applauded for its scientifically responsible approach. But some of the experts on the panel have some concerns about the scientific quality of the country's proposals.

Some projects look more like plans to create networks between national universities, they say, or attempts to build and strengthen national industries, rather than to develop cutting-edge research infrastructures. One project aims to build a knowledge alliance between several universities to help develop foundry and metallurgy industries, but contains no ideas for what research would be conducted in this area. Instead, it focuses on how the institutions can be linked up easily, sited as they are along major highways.

Out of a total of 60 points that each proposal could be awarded, the highest mark was 45.3; the majority of projects came in at just over half marks. As one scientist on the assessment panel (from a research-intensive member state) commented, only projects awarded the equivalent of 54 points or more would be considered for funding in their home nation. There are also widespread concerns in Europe that the new member states lack the experience to manage large infrastructure projects, including handling budgets, procurement and legal aspects. Insiders at the ELI say that this lack of experience is beginning to show, in preparing accounts for example.

The European Research Advisory Board, an independent advisory committee to the European Commission, echoes these fears in a report published in October. The board is concerned that the power given to member states, to decide which projects to fund with structural funds, directs investment towards building national capacity, rather than cutting-edge research.

"Some Polish
research
infrastructure
projects look
like attempts to
build national
industries."

The board recommends that some of the structural funds be held back in a central pot, to be allocated to projects judged to be of a high standard by experts, and which would serve pan-European needs. Although this approach may be better for research as a whole, it doesn't address the difficulties faced in the new member states.

These difficulties are not confined to the newer member states, as those countries involved in building ITER, the fusion test reactor struggling to life near Cadarache, France, have learnt the hard way. Legal and managerial expertise that is crucial to make such projects work must be actively sought and shared. For example, the European Investment Bank's initiative to help new member states prepare financial proposals for major projects could be extended to see projects through to later stages. And a portion of structural funds earmarked for research infrastructure could be set aside to train scientists as managers.

Structural funds for research infrastructure should continue to flow, but more international support is needed to ensure that the structures built around them are sound.

\section{Asbestos scandal}

\section{Irresponsible policies could cause an epidemic of malignant lung disease.}

$\mathrm{V}$ iewed through an electron microscope, asbestos fibres look like thin glass straws, some no more than a fraction of a micrometre wide. If inhaled, they penetrate the soft alveoli of the lungs and the membranes that line the chest cavity. And there they stay. Over time, damaged cells can cause a malignant disease called mesothelioma, which often kills people, horribly, less than a year after diagnosis.

Before the widespread industrial use of asbestos began in the late nineteenth century, malignant mesothelioma was unheard of, yet it is now responsible for tens of thousands of deaths around the world every year. After the link between asbestos exposure and the disease was convincingly made in 1960, responsible nations eventually took strong measures to remove the mineral from commercial products and to halt mining and export. Less responsible nations did not; this is a scandal that deserves wider attention.

The United States has still not banned asbestos, despite the millions of dollars spent to clear it from homes and from communities near mines. And Canada has been criticized for plans to expand asbestos mining operations, which export the material to India, Indonesia and the Philippines. Although Canada enforces strict guidelines on asbestos use at home to protect its own people, those in countries to which it

sends the mineral have little or no protection. Asbestos exported from Canada and other countries including Russia, Brazil and Kazakhstan is routinely mixed into building materials and consumer products, prized for the same durability that makes it troublesome for living tissue. Owing to the long time between exposure and the onset of disease, 30 years or more, the asbestos trade in North America and elsewhere is creating an epidemic that may take decades to peak and subside.

The minerals industry has long tried to convince regulators that white asbestos - or chrysotile - is safe when handled properly. It argues that only the already controlled forms - blue and brown asbestos, known collectively as amphibole - are of concern.

To support this, industry advocates point to scientific data and studies. Yet although the relevant literature is a mire of conflicting results, this should not be seen as an endorsement of their position. Rather, it reflects a string of industry-sponsored studies designed only to cast doubt on the clear links between chrysotile and lung disease. These are familiar tactics and several countries, including Britain, have seen through them and made the correct decision to ban all forms of asbestos, all of which have been proven to be carcinogenic in humans.

Meanwhile, researchers are finding new causes for concern with other natural fibrous minerals such as erionite (see page 884). Complacency is the problem. Much of the developed world has seen asbestos removed from public spaces, leaving in many minds a false sense of security. The

$\rightarrow$ NATURE.COM To comment online, click on Editorials at: go.nature.com/xhunqv public should once again be made aware of the risks associated with exposure to mineral fibres, as well as some man-made fibres. And governments must ban the extraction, processing and use of materials that can cause serious disease. 